\title{
薄板鋼構造による某事務所建築の構造実験報告
}

はじめに 近時、比較的 Low Cost で建築物を不燃 北し、且つ森林資源を保護するという目的で、所謂、薄 板鋼構造が出現し、世の注目あびている。

本報告は、このような薄板鋼構造に対する一資料を得 るため、この構造で造られた事務所建築の骨組に対して 行つた構造実験についての報告である。

§1. 構造の概要 この建物の建坪は $278.4 \mathrm{~m}^{2}$ (84.5

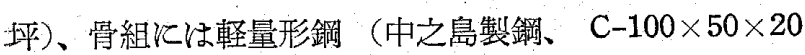
$\times 3.2 ， \mathrm{C}-100 \times 50 \times 20 \times 2.3)$ を使用乙、地震力並びに

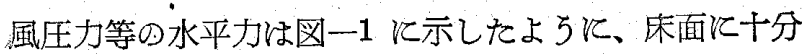
なすごかいを配置して（a)，(c)，(e) の三ラーメン、

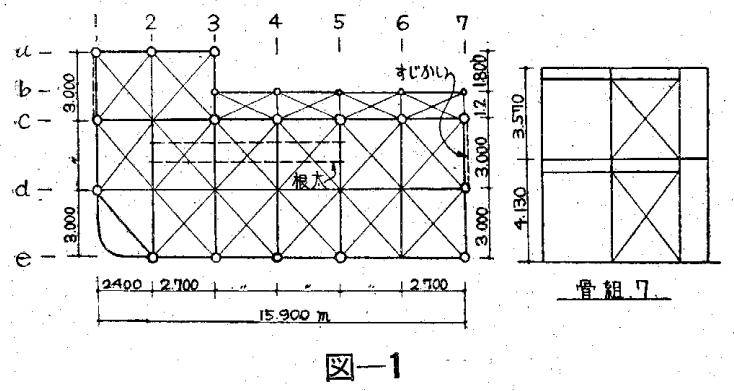

及び (1)，(7) そ配置した側面すじかいたもたせるとと そした。な拓計算は日本建築学会薄板鋼構造計算規準案 《よつた。

§2. 実験の概要と目的 実験は、 3 月 25 日から 29 日まで約 1 週間にわたつで行つた。

実験は次の三つよりなつている。

（i）スパン方向骨組江対する実験一（静的実験 I )

この実験法建物をスパン方向に静的に引張り、主とし て床面すじかいと、側面すじかいの効果をみるため行つ t。

（ii）桁行ラーメンV対する実験一（静的実験 II)

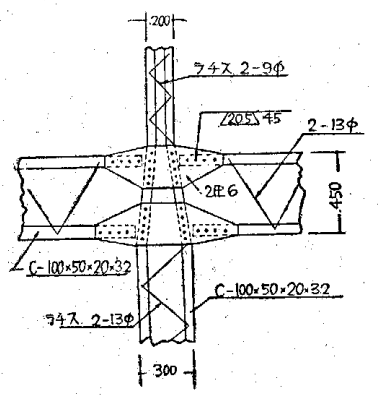

図-2
桁行方向は、側面すじか いがとれなからたため、水 平力はラーメンによつて抵 抗させることにした。との ため図一2 亿示したように 柱を組立柱にしなければな らなくなり、その上柱梁の 仕口子薄板鋼構造として は、かなり無理なるのとな つてしまつた。

* 東京工業大学教授 工博 ** 同助教授、***同助手 **** 同研究生

$\begin{array}{rrrrl}\text { 正会 } & \text { 二 } & \text { 見 } & \text { 秀 } & \text { 雄 }^{*} \\ \text { 同 } & \text { ○藤 } & \text { 本 } & \text { 盛 } & \text { 久 }^{* *} \\ \text { 同 } & \text { 小 } & \text { 林 } & \text { 啓 } & \text { 美*** } \\ \text { 同 } & \text { 杉 } & \text { 山 } & \text { 圭 } & \text { 二 }^{* * * *}\end{array}$

この実験はこのラーメンを静的に引張つて、変形状 沅、ラチスの応力、柱脚の固定の影響等を検討するのが 目的である。

(iii) 振動実験

この種の鉄骨構造物では、しばしば、その振動性状が 問題になり、既に二三の建物についての実験結果が報告 されている。本建物に対してる、裸鉄骨についてではあ るがデーターをとるいみで、桁行、及びスパン方向汶対 しての週期、減衰性等を調査した。

§3. 静的実験 I一（スパン方向骨組に対する実験）

3. 1 実験方法 図-3 と示したように、チェンブロ ックとテンションメーターを併用して荷重を作用させ

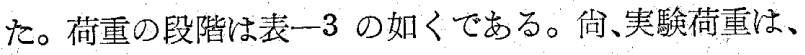
最大の No. 4 の合計が設計荷重の約 $1 / 2$ である。

\begin{tabular}{|c|c|c|c|c|c|c|c|}
\hline \multicolumn{3}{|c|}{ No. } & 0 & 1 & 2 & 3 & (4) \\
\hline \multirow{2}{*}{ 荷重 } & \multirow{2}{*}{$\mathrm{kg}$} & $\mathrm{T}_{2}$ & 0 & 200 & 500 & 800 & 1000 \\
\hline & & $\mathrm{T}_{1}$ & 0 & 300 & 750 & 1200 & 1500 \\
\hline \multicolumn{8}{|c|}{ 表-4 } \\
\hline 記号 & 状 & 況 & 点数 & $\begin{array}{l}\text { W.S.G. } \\
\text { 校 数 }\end{array}$ & 但所 & 備 & 考 \\
\hline - & & & 1 & 2 & 6 & $\begin{array}{l}\text { 㕅 } \\
\text { 力 }\end{array}$ & 面すし \\
\hline$=$ & & & 9 & 18 & 9 & & \\
\hline \pm & & & 15 & 30 & 1 & & \\
\hline
\end{tabular}

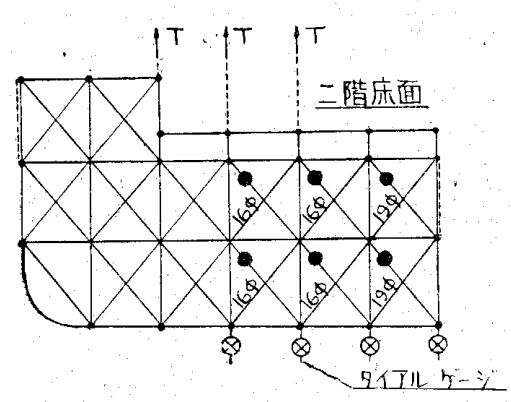

W.S.G. 貼付個 所と、ダイアルゲ 一ジ設置個所は、 図一3 並びに表一 4 に示した如くで あり、W.S.G.の 点数诘計 102 点で ある。

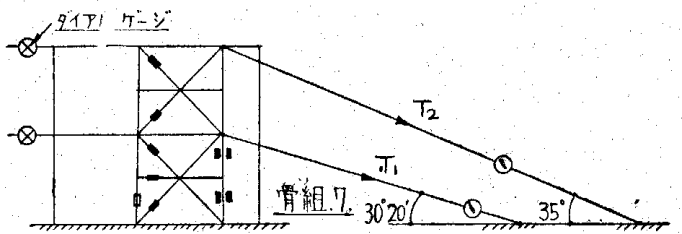

図-3 


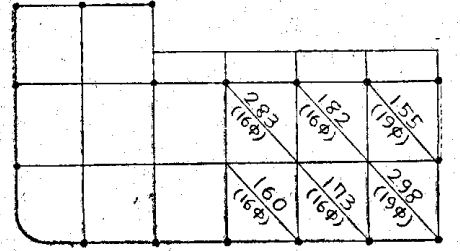

図一4すじかいの元応力（ton）
3. 2 床面すじか いの元応力 実験飞 先立つて、床面すじ かいの元応力をしら ベるため、ターンバ ックルを全部ゆる め、メーターの読み を0にして、再びターンバックルを締めた後の元応力を 調查した。この䟢ターンバックルを締めた占には全く何 も知らさず勝手に締めるに采かせた。結果は図一 4 の如 くである。

3. 3 建物の変形 図一5, 図一6は各荷重段階に於け る建物全体の変形を示したるのである。
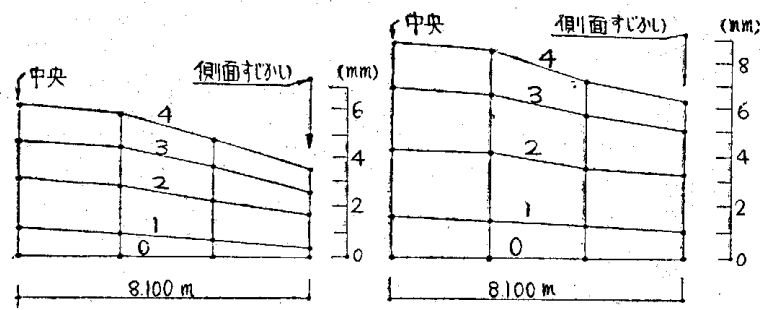

図一5 二階床面变位

図-6 屋根面変位

3. 4 すじかいの 応力分布 荷重段階 （4）の場合の二階床 面すじかいの応力分 布を図一7，側面す じかいの場合を図一 8 に示した。

3. 5 結果の考察

(i) ターンバッ クルを締めることに よるすじかいの元応 力は意外に大きく。 $16 \mathrm{~mm} \phi$ 以下の場合 では、この元応力の みで鉄筋の長期許容 応力度 $1600 \mathrm{~kg} / \mathrm{cm}^{2}$ に達する場合子考え られる。本建物の場

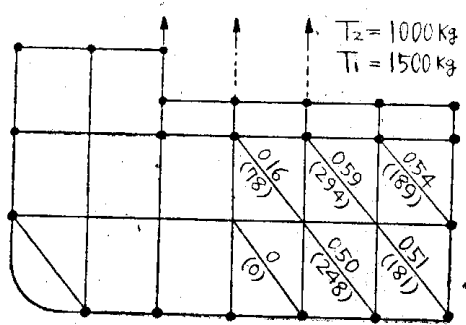

図-7

二階床面すじかいの応力 (ton). 荷重的 No. 4 ( ) 内は $\sigma \mathrm{kg} / \mathrm{cm}^{2}$

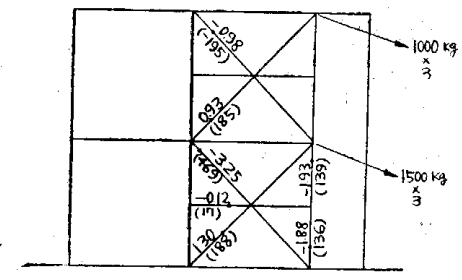

図一8

側面すじかいの応力 (ton) 荷重は No. 4 ( ) 内尘 $\sigma \mathrm{kg} / \mathrm{cm}^{2}$

合、廊下に配置した $9 \mathrm{~mm} \phi$ のすじかいなどでは、建方 時にあまりにもしめすぎたため、端部のボールトが剪断 されて跳んでしまつたこともあつた。ターンバックルに は調子のよいものと悪いものとがあり、締め方にかなり なむらを生じ、そのためすじかいの「きき」が一様でな くなる恐れがある。何れとしても、このような構造の場 合は、構造全体が床面のすじかいに全く期待しているの であるから、特に注意しなければならないと思う。

（ii）構造全体としての変形は、最大の荷重段階 (4) で、屋根面中央で約 $9 \mathrm{~mm}$, 二階床面中央では約 $6 \mathrm{~mm}$
の変形を生じている。(図一5〜6) 設計水平荷重は、屋根 面で 5.7 ton, 二階床面て 8.5 ton であるから、設計荷 重時にはこの約 2 倍の変形を生ずることが予想される。 になり、かなり大きい。従がつて床面や、壁の仕上材料 によつては亀裂を生じたりすることも考えられるので、 特に細長い建物の場合には注意を要する。

変形をどの程度に括さえたらよいか、変形を少なくす るにほどうしたらよいか等の問題は、建物の振動性状之 も関聯し、今後にのこされた極めて重要な課題である。

(iii) 実験の結果は、引張をらける床面すじかいの応 力は、以外机さい（図-7）。之は、すじかいの元応力 力を負担するためと思われる。従がつて、ターンバック ルによつて相当大きな元応力を生じているとしてもとれ 程心配はないようである。ただ、（i）でのベたように、 すじかいのしめ方にさらがあると、危険な場合も考光ら れるから、何らかの方法ですじかいの「きき」は一様に したいものである。

(iv) 側面すじかいの応力は、設計上では、弱張力の みにきくと仮定して計算を行つているのであるが、この 建物のようにC形鋼を使つてかなりガッチリしたすじか いの場合は、当然予想されることではあるが、この仮定 は全く成立していない（図一8）。むしろ圧縮に対して余 計にきいてしまつている。リミットデザイン的には勿論 差支えはないと云觉るが、压縮にきいているすじかいが 座屈してから引張がフルにきくというのでは、すじかい が、ガッチリしているだけに建物全体対してかなりな 悪影響があるものと思われる。やはりすじかい類は可及 的丸棒を使用し、ターンバックルを適当にしめて、その 引張元応力をうまく利用するという方法が好ましいので はなかららか。

（v）一部の仕曰隹いて、床面筋違からの偏心引張 のため、図一9 そ示した ような局部変形が認めら れた。このような点は通 常の鉄骨構造の場合はあ まり問題にならないので あるが、薄板鋼構造の場 合は、出来るだけ偏心を 避けるとか、やむをえな い場合には、ウエブを補 剬するとか、筋違類の取

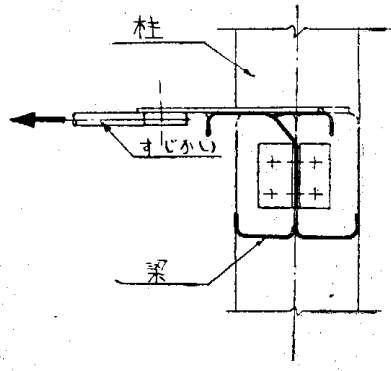

図一9偏心引張による局部 变形 即ち屋根面中央で約 $18 \mathrm{~mm}$, 二階床面中央では $12 \mathrm{~mm}$ のため（図一4）、圧縮側に働くすじかいが、かなりな応

§4. 静的実験 II-（桁行ラーメンに対する実験）

4. 1 実験方法 図一10，11 に示したよらに (a) ま ーメンのまわりの床面すじかいをゆるめ、このラーメン゙ を引張つて、変形、応力等を測定した。 


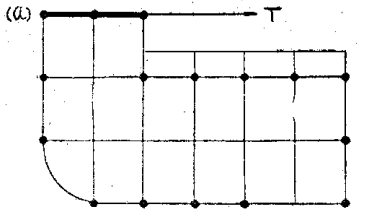

図 -10
荷重の段階は表-5 に示 した。実験荷重は、最大の No. 4 が略設計荷重に等し い大きさである。

W.S.G 貼付個所、ダイ ヤルゲージ設置個所は、表 -6 及び図-11 に示して如くであり、W.S.G の点数は 総計 110 点である。

表一5 荷重の段階

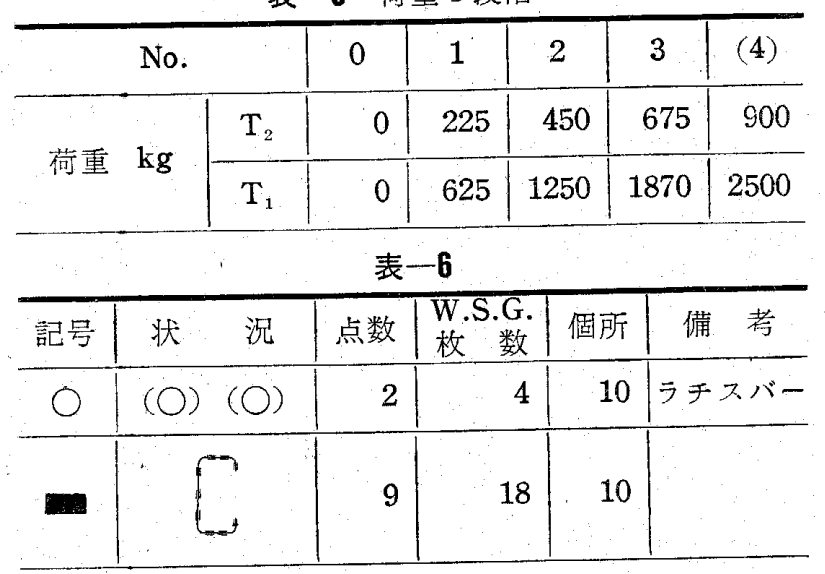

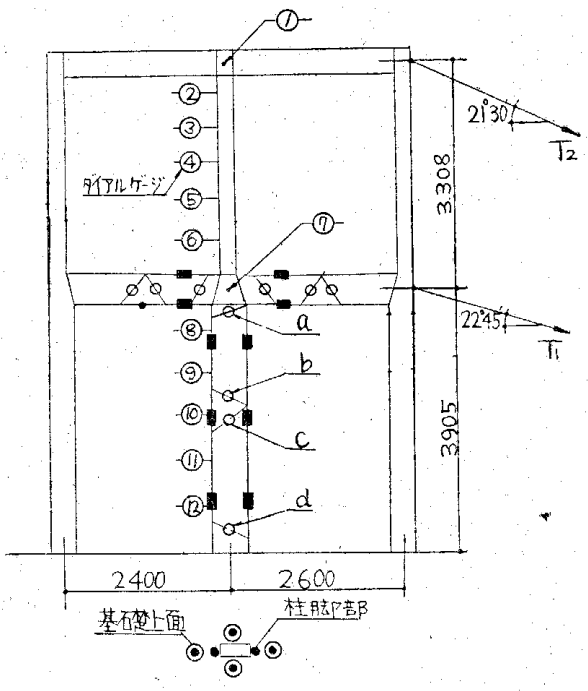

図-11

4. 2 柱脚の回転 図一12亿、柱脚に取付けたダイア ルゲーシ $\mathrm{D}_{1}, \mathrm{D}_{2}$ の読みを示した。柱脚に取付けた他の ダイアルゲージは明確な動をを示していない。

4.3 各部の応力 詳細は省略して、一例として、図 一11に示した各ラチスバー (2-13 を表一7 と示した。

$$
\text { 表一7 ラチスバーの応用 }
$$

\begin{tabular}{|c|c|c|c|c|c|c|c|c|}
\hline \multirow{2}{*}{$\begin{array}{l}\text { 荷 } \\
\text { 重 }\end{array}$} & \multicolumn{2}{|l|}{ a } & \multicolumn{2}{|l|}{ b } & \multicolumn{2}{|l|}{ c } & \multicolumn{2}{|l|}{ d } \\
\hline & $\sigma \mathrm{kg} / \mathrm{cm}^{2}$ & $D$ ton & $\sigma \mathrm{kg} / \mathrm{cm}^{2}$ & D ton & $\sigma \mathrm{kg} / \mathrm{cm}^{2}$ & $D$ ton & $\sigma \mathrm{kg} / \mathrm{cm}^{2}$ & D ton \\
\hline 1 & 55 & 0.14 & 94 & 0.26 & 79 & 0.22 & 73 & 0.20 \\
\hline 2 & 107 & 0.28 & 170 & 0.46 & 154 & 0.40 & 134 & 0.36 \\
\hline 3 & 170 & 0.46 & 269 & 0.72 & 242 & 0.64 & 222 & 0.60 \\
\hline 4 & 248 & 0.66 & 341 & 0.90 & 345 & 0.92 & 305 & 0.82 \\
\hline
\end{tabular}
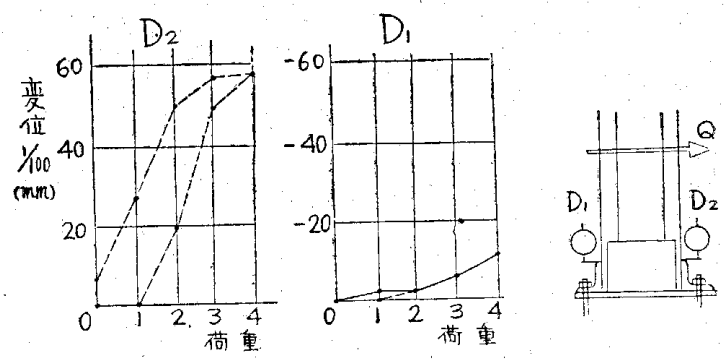

冈一12 柱脚 $\sigma$ 变位

4. 4 柱の撓み曲線 図一14 (c) 飞示した変形注荷重 段階 (4) 飞対応するものである。

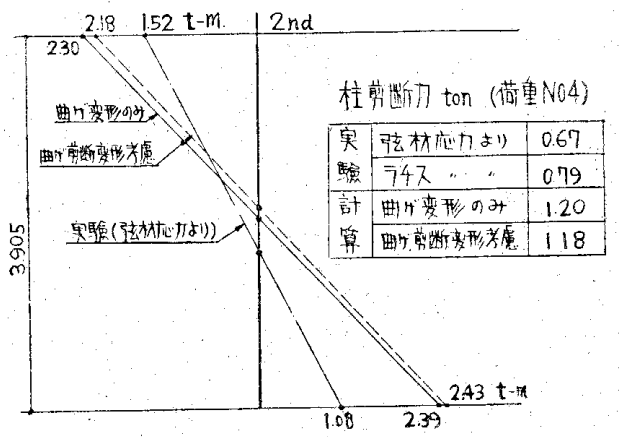

図一13 柱曲げモーメント、剪断力（荷重 No. 4)

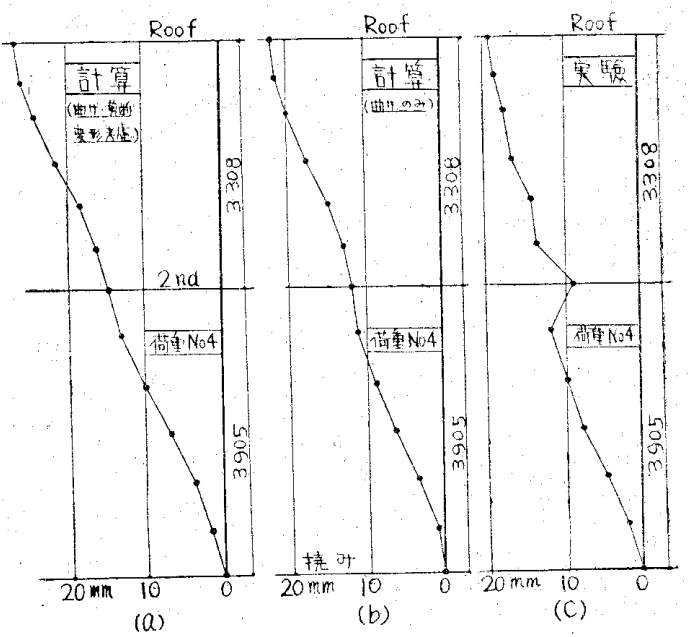

図一14 柱の撓み出線

4. 5 結果の考察 柱脚の設計に際してほ、骨組が固 定のラーメンを構成していることを考えてかなり剖に設 計したつるりでいそところ、その結果は、基礎上面のも のは、あ季り明確な動きを見せなかつたが柱のつ忛根の 変位は予想以上に大きかつた。(図一-12)

図一12 亿於いて、 $D_{1}$ と $\mathrm{D}_{2}$ の変位がが なりことなるのは、変位は主にベースプレ 一ト下面と、基礎コンクリート上面の間の ガタにあるためと思われる。。即ち $\mathrm{D}_{1}$ の 側は浮上りであるため、ベースプレートの

*ここのような柱脚の固定度の諸問題飞 対しては、横浜国立大学、田口武一博 士の一連の研究がある。 
変形と、アンカーボールトの昰とによっているため、こ の程度の荷重では、それ程大きくなく、(荷重 4 で柱脚 の曲げモーメントは $1.08 \mathrm{t}-\mathrm{m}$ )、逆に $\mathrm{D}_{2}$ の側は圧縮で あるため、ガタの分だけ変形しているからであるう。

この柱脚回転の影響は、曲げモーメントの分布、撓み 曲線に明白にあらわれている。

（ii）実験と比較するため、通常の理論及び剪断変形 る考光を場合の二つの場合について計算を行つた。図一 13は実験で測定した弦材応力から算出した一階柱の曲げ モーメント分布と、柱の剪断力とを之等の理論值と比較 したるのである。な招、剪断力中にラチスよりとあるの は、測定されたラチスの応力から直接算出された剪断力 であり、何れる荷重は最大の段階 (4) の場合である。

実験値は理論値に比へて著しく小さい、之は、このう ーメンが、之と直角方向の梁で主体とつながつているた め、この梁を通して荷重が相当程度流れてしまうためで あると思われる。従がつて、之には何等本質的な意味は ないが、反曲点の位置が実験では下がつているというと とは、明らかに（i）でのべた柱脚回転の影響であり、こ の影響が馬鹿にならないととを示している。従がつてて のようなラーメンの設計に際しては、何らかの形で柱脚 回転の影響を考虑しなければならないであらう。

(iii) 図-14 (a), (b), (c) \& (ii) 同様、荷重 (4) 飞対して理論と実験より得られた撓み曲線を比較したも のである。

この場合、この柱に加わる曲げや剪断力は、理論值に 比して実験值の方がかなり小さい拘わらず（図一 13)、理論と実験との差は々れ程著しくない。之は、や はり (ii) 項同様、理論計算《入つていない柱脚の固定 度の影響が大きいととを示している。

(iv）通常の理論値と、更汇剪断変形をも考兄て理論 值怔力分布にはそれ程大きな差をもつていないが、 撓みには若干の差を生ずる。

（v）実験 II 飞際しては、薄板鋼構造としての特徵 恃何等認められなかつた。

\section{§5. 振動実験}

静的実験の場合と同じ状態で自由振動実験を行つた。

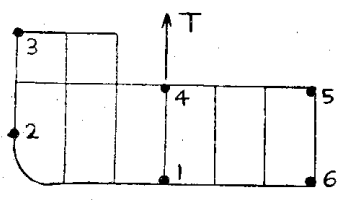

(a) 实聽 Nol

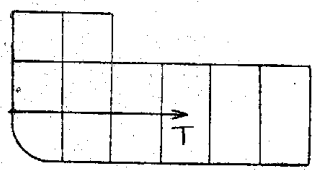

(C) 实聽 N03

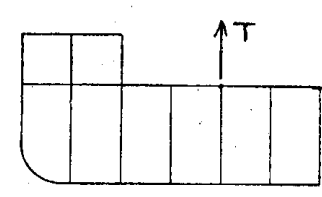

(b) 实龭 No2

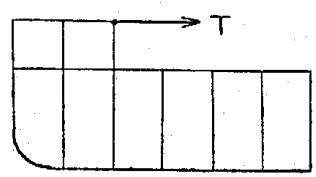

(d) 实喛 NO4.
図-15
整呀 NoI

R-2 HWWW Whanionn

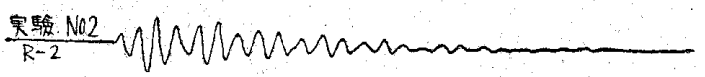

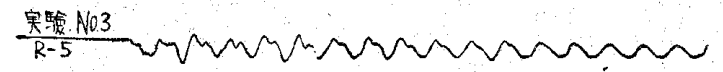

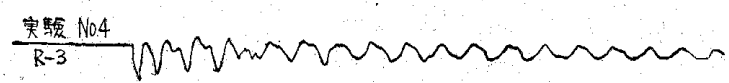

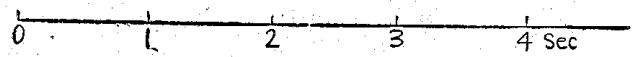

図-16

屋根面の図一-15亿示した位置飞水平力を加兄て初期撓 みを与光、自由振動を生ぜし、建物の各部（各階床上、 及び基礎上面）の振動を振動計によつて測定した。使用 した振動計は石本式携带用加速度計 $\mathrm{T}=0.1 \mathrm{sec}$ で、電 磁式記録を行つた。実験は表一8 そ示したよ 万に 4 種類 である。

測定した記録の代表的なるのを図一16に示した。之ら の結果から求めたスパン方向、並びと析行方向の週期及 び減衰性は表一8 亿示した如くでめる。

表一8 振 動 実 験

\begin{tabular}{|c|c|c|c|}
\hline & 験 & 週 期 & 減衰常数 \\
\hline No. 1 & $\begin{aligned} \text { スパン方向、中央加力 } \\
\text { 図-15 (a) }\end{aligned}$ & $0.16 \mathrm{sec}$ & 0.070 \\
\hline No. 2 & $\begin{aligned} \text { スパン方向、偏心加力 } \\
\text { 図一15 (b) }\end{aligned}$ & $0.16 \mathrm{sec}$ & 0.040 \\
\hline No. 3 & $\begin{aligned} \text { 桁行方向、中央加力 } \\
\text { 図-15 (c) }\end{aligned}$ & $0.28 \mathrm{sec}$ & 0.010 \\
\hline No. 4 & $\begin{aligned} \text { 桁行方向、偏心扣力 } \\
\text { 図 }-15 \text { (d) }\end{aligned}$ & $0.27 \mathrm{sec}$ & 0.012 \\
\hline
\end{tabular}

以上の結果、次の上う洘察される。

(i) この建物では、スパン方向のトラス構造の方 が、桁行のラーメン構造より剛性、減衰性は大である。

(ii) この振動実験の結果は、骨組のみの結果である ので、直接他の結果と比較できないが、特に杵行のラ一 メンは溶接構造であるため減衰性が極めて悪い。

（iii） 構造体の重量が軽いので、仕上材料が建物全体 の剛性、減衰性に及ぼす影響は著しく大きいと考党ら れ、従がつて、この種構造物の振動性を論ずるには、壁、 床と併せ考えることが必要である。

をわりに，実験漈しては、多くの方々の御協力をい ただきました。中之島製鋼の山形さん、八幡製鉄の高木

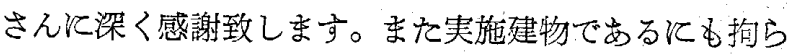
ず実験のチャンスを与えて下さつた巴組鉄工所の野間さ ん、松下さん、現場で直接実験に当られた設計二課の佐 藤さん、技術課の蛯名さん、大花さん、現場主任の高橋 さん等巴組鉄工所の全面的な援助をいただきむした。な 和実験やデーター整理住尽力された、大学院学生の平野 君、学部学生の斎藤、谷口、荻野、深江、宮崎、清田、 矢部、松村、松下、高橋、毛吕、栄の諸君、並びそ研究 生の大藤君汇感謝致します。 